\title{
PERFORMANCE OF SYSTEM OF RICE INTENSIFICATION WITH CONVENTIONAL METHOD OF RICE CULTIVATION
}

\author{
A. P. Mondol, P. K. Biswas* and M. S. Islam \\ Department of Agronomy, Sher-e-Bangla Agricultural University, Dhaka- 1207 \\ *Corresponding author, E-mail: parimalbiswas@hotmail.com
}

(Received: 20 June 2017, Accepted: 23 August 2017)

Key words: SRI, Conventional method, Boro season, Rice varieties

\begin{abstract}
A field experiment was conducted in Sher-e-Bangla Agricultural University research field of Bangladesh during December 2012 to May 2013. This experiment was tested for two planting method consisting $\mathrm{CM}$ planting method $\left(\mathrm{P}_{1}\right)$ and System of Rice Intensification (SRI) planting method $\left(\mathrm{P}_{2}\right)$ against five rice (Oryza sativa) varieties named BR $16\left(\mathrm{~V}_{1}\right)$, BRRI dhan29 $\left(\mathrm{V}_{2}\right)$, BRRI dhan50 $\left(\mathrm{V}_{3}\right)$, BRRI hybrid dhan2 $\left(\mathrm{V}_{4}\right)$ and Heera $4\left(V_{5}\right)$. The experiment was laid out in split-plot design with three replications. All yield parameters showed the highest for SRI with higher effective tillers hill-1 (41.13), longer panicle $(28.15 \mathrm{~cm})$, higher total grains panicle ${ }^{-1}$ (216.89), number of filled grains panicle $^{-1}$ (166.82) as a result 10.17 and $12.5 \%$ higher grain yield and straw yield, respectively were observed in SRI than the conventional method.
\end{abstract}

\section{Introduction}

Most of the Asian countries accept rice as their staple food. Asian countries cover near about $75 \%$ of the world's rice supply (Cabangon et al., 2002). SRI is a rice cultivation method developed in Madagascar which increase rice productivity with reducing the external inputs like fertilizers and herbicides (Thakur et al., 2009 and Vermeule, 2009). Sustainable rice production would be possible by increasing yields on the same piece of land reducing the input like water, chemicals, fertilizers and labor (Bouman et al., 2005; Mati and Nyamai, 2009). SRI consists of some principles including transplanting of younger seedlings $(<15$ days $)$ at wider spacing in square grid pattern, only one seedling hill- ${ }^{-1}$, water management with alternate wetting and drying, mechanical weeding and use of organic compost fertilizer instead of chemical fertilizer (Stoop et al., 2002). Use of younger seedlings, wider spacing and a single seedling hill-1 facilitate the utilization of the resource to develop stronger individual plants in the rice field.Younger seedling in transplantation provide a longer vegetative growth period and single seedling reduce the competition and help to minimize the shading effect of lower leaves, as such lower leaves remain photosynthetically active for longer time and root activity remain higher for longer period as the supply of oxygen and carbohydrate to the root is increased (Horie et al., 2005). Supply of Cytokinin to the lower leaves increase due to higher root activity, delay the senescence and help to maintain photosynthetic efficiency at the letter stage that result higher yield compared to CM (San-oh et al., 2006). But as AWD is practiced in SRI, it enhanced the supply of oxygen to the root zone that reducing the arenchyma and causing stronger, healthier root system to maximize the nutrient uptake (Stoop et al., 2002). Besides, the number of productive tiller is higher in SRI (217\%) over the CM (Krishna et al., 2008). As such, the experiment was conducted to find out the proper method of sowing of rice in SRI and compare to conventional method 


\section{Materials and Methods}

This experiment was conducted at the Agronomy field of Sher-e-Bangla Agricultural University, Dhaka-1207 with three inbreed rice varieties viz., BR16, BRRI dhan29, BRRI dhan50 and two hybrid var. BRRI hybrid dhan4 and Heera4 in two planting system(SRI and CM). The experiment was accomplished in a split-plot design with three replications. A 34 day old seedlings were transplanted maintaining spacing $25 \mathrm{~cm} \times 15 \mathrm{~cm}$ in CM with two seedlings hill $^{-1}$, where for SRI, 16 day old seedlings with one seedlings hill-1 ${ }^{-1}$. The unit plot size was $5 \mathrm{~m} \times$ $2.4 \mathrm{~m}$ maintaining $30 \mathrm{~cm} \times 30 \mathrm{~cm}$ spacing. Two hand weddings were done for conventional plots, first at 16 days after transplanting followed by second at 15 days after first weeding. In SRI plots, two hand rakings were done after hair line crack developed in the plots. In SRI plots, Alternate Wetting and Drying (AWD) was practiced and in conventional plots continues flood irrigation was applied as per need of plants. The $46 \% \mathrm{~N}$ containing urea was top-dressed in three equal installments at the rate of $260 \mathrm{~kg} \mathrm{ha}^{-1}$ and $266 \mathrm{~kg} \mathrm{ha}^{-1}$ for inbreed and hybrid, respectively. The first one after seedling recovery, second at vegetation stage and another at 7 days before panicle initiation. Triple super phosphate (TSP), muriate of potash (MoP), gypsum and zinc sulphate, $\left(100,120,110\right.$ and $\left.10 \mathrm{~kg} \mathrm{ha}^{-1}\right)$ for the inbreed varieties and 125, 120, $110,15 \mathrm{~kg} \mathrm{ha}^{-1}$ for the hybrid was applied as basal. All other intercultural operations were done as and when necessary.

Plants were infested with rice stem borer (Scirphophaga incertolus) and leaf hopper (Nephotettix nigropictus) to some extent which were successfully controlled by applying Diazinone @ $10 \mathrm{ml} / 10$ liter of water for 5 decimal lands and by Furadan $5 \mathrm{G}$ at the rate of $10 \mathrm{~kg} / \mathrm{ha}$. The grains were cleaned and sun dried to a moisture content of $14 \%$. Straw was also sun dried properly. The collected data were analyzed by using MSTAT-C package and the mean differences were adjusted by LSD test.

\section{Results and Discussion}

\section{Number of effective and ineffective tillers hill ${ }^{-1}$}

The highest number of effective tillers hill ${ }^{-1}$ was produced in the planting method of SRI than the conventional method (Table 1) which was $250.04 \%$ higher than conventional method. Among the variety, highest no. of effective tiller/plant was obtained from BR16 $\left(\mathrm{V}_{1}\right)$. In interaction showed that the variety BR16 with SRI gave highest tillers / plant than th other treatment.

Krishna et al. (2008) was also found $217 \%$ higher number of effective tillers in SRI than CM. These might be due to use of tinny seedlings, wider spacing and efficient use of nutrients from the soil as the root system was well developed in SRI. Thakur et al. (2011) reported 38.5\% increases in root length of SRI over CM. Wider spacing offered less interplant completion for resources. On the other hand, in SRI seedlings are transplanted at two leaves stage (at third phyllochron), first tillering start at the fourth phyllochron (Katayama,1951) that covers 40\% of total tillering and get a chance of profuse tillering. As in CM transplanting is done after third phyllochron lead to a bigger loss in total tillers. Ginigaddara and Ranamukhaarachchi (2011) also supported that younger seedlings had ability to produce higher number of tillers hill ${ }^{-1}$ than older one. Number of ineffective tillers hill ${ }^{-1}$ was higher in SRI than the CM. This might be due to higher number of tertiary tillers in SRI and most of the tertiary tillers inactive for production. 
Panicle length

SRI produced significantly longer panicle $(28.15 \mathrm{~cm})$ than the CM $(25.77 \mathrm{~cm})$. Panicle was $9.25 \%$ longer in SRI than the conventional system (Table 1). The $\mathrm{V}_{2}$ produced the longest panicle in SRI $(30.53 \mathrm{~cm})$ that was followed by $\mathrm{V}_{5}(29.12 \mathrm{~cm})$ in SRI while V3 $(23.52 \mathrm{~cm})$ produced the shortest panicle in $\mathrm{CM}$ (Table 1). Among the interactions, P2V2 produced the longest panicle but all the five varieties produced longer panicle in SRI than CM.

Biswas et al. (2013); Thakur et al. (2011) and Latif et al. (2005) also revealed the similar findings of higher panicle length in SRI. Longer panicle of SRI might be due to higher dry matter accumulation in the plant, higher photosynthetic rate and better utilization of the nutrients. Integration of limited irrigation and mechanical weeding in SRI, increase the aeration by dissolving oxygen from the irrigation water enhancing the root: shoot ratio (Uphoff and Randriamiharisoa, 2002).

\section{Total number of grains panicle $e^{-1}$}

The higher number of grains panicle ${ }^{-1}$ was produced in the planting method of SRI (216.89) than the CM (172.58). Which was 25.67\% higher in SRI (Table 1). Each of the five varieties, $\mathrm{V}_{1}, \mathrm{~V}_{2}, \mathrm{~V}_{3}, \mathrm{~V}_{4}$ and $\mathrm{V}_{5}$ produced $17.19,25.63,37.31,22.24$ and $26.25 \%$ higher grains panicle $e^{-1}$ in SRI than CM (Table 1). Thakur et al. (2011) also agreed that SRI produced higher number of total grains panicle ${ }^{-1}$ than standard management practice. Bozorgi et al. (2011) suggested that wider spacing gave maximum number of grains panicle ${ }^{-1}$.

\section{Filled grains panicle ${ }^{-1}$}

SRI (166.82) produced significantly higher number of filled grains panicle ${ }^{-1}$ than the CM (124.41) (Table 1) which was 34.09\% higher in SRI than the CM. Maximum number of filled grains panicle $e^{-1}$ were produced by $V_{5}$ (186.37) that was statistically similar with $V_{2}$ (166.80), $V_{3}(172.23)$ and $V_{4}$ (182.97) in SRI planting system followed by $V_{2}(157.70)$ and $V_{5}$ (133.77) in $\mathrm{CM}$ and minimum number of grains panicle $e^{-1}$ by $\mathrm{V}_{3}$ (92.37) in $\mathrm{CM}$. These result reveled that SRI produced higher filled grains panicle $e^{-1}$ than $\mathrm{CM}$ in respect of variety. Higher number of filled grins panice $e^{-1}$ in SRI might be due to maximum utilization of solar radiation, availability of nutrients on the root zone and better uptake of nutrients by the developed root system and long lasting lower leaves of each of the hill as photosynthetically active. Ali et al. (2013) observed higher number of filled grain panicle ${ }^{-1}$ from 15 day old seedling with intermittent irrigation, which was two important principle of SRI, than 30 day old seedling with continuous flooded plot. Thakur et al. (2011) also obtained the similar result of filled grain panicle ${ }^{-1}$ in SRI.

\section{Weight of 1000 - grains}

The higher weight of 1000 -grains $(25.60 \mathrm{~g})$ was obtained from CM and lower $(24.13 \mathrm{~g}$ ) from SRI (Table 1). The $\mathrm{V}_{5}$ produced maximum 1000- grains weight in $\mathrm{CM}$ that was followed by $\mathrm{V}_{5}$ $(29.24 \mathrm{~g})$ in SRI and $\mathrm{V}_{4}(28.64 \mathrm{~g})$ in CM. Minimum 1000- grains weight was recorded for $\mathrm{V}_{3}$ $(19.83 \mathrm{~g})$ in CM that was statistically similar with $V_{2}(20.67 \mathrm{~g})$ and $V_{3}(19.69 \mathrm{~g})$ in SRI (Table 1). Mannan et al. (2009) also opined that heavier grain weight was found in early planted crop and grain weight decreased with the delayed transplanting.

\section{Grain yield}

SRI produced significantly higher $(10.17 \%)$ yield $\left(9.10 \mathrm{t} \mathrm{ha}^{-1}\right)$ than $\mathrm{CM}\left(8.26 \mathrm{t} \mathrm{ha}^{-1}\right)$ (Table 1$)$. The $V_{1}, V_{2}, V_{3}, V_{4}$ and $V_{5}$ produced $14.29,8.31,8.57,10.22$ and $9.70 \%$ higher grain yield in SRI than the CM with the respective varieties (Table 1). In SRI, plant received longer growth duration as it was transplanted in very tiny stage whereas in CM transplanted in old aged with shorter time. Due to longer vegetative growth, tiller production was higher in SRI than CM that 
ultimately leads to lower yield in CM. On the other hand, number of effective tillers hill-1, panicle length, number of total grains panicle ${ }^{-1}$, number of filled grains panicle ${ }^{-1}$ was higher in SRI than CM which might be the reason of higher yield in SRI. Ginigaddara and Ranamukhaarachchi (2011) assured that the transplanting with younger seedlings in water saving rice production system produced more effective tillers hill ${ }^{-1}$, filled grains plant ${ }^{-1}$, panicle length compared to CM. Suganthi et al. (2003) suggested that delayed transplanting significantly reduced the number of productive tiller which reduced the grain yield. Better yielding performance of SRI might be due to higher net photosynthetic rate of the fully expanded leaves at mid-tillering and improved utilization of photosynthates in the grain-filling stage (Song et al., 2013). Krishna et al. (2008) also observed that SRI produced 15.65\% higher grain yield over traditional method.

\section{Straw yield}

Higher straw yield was produced in the planting method of SRI $\left(9.48\right.$ tha $\left.^{-1}\right)$ than conventional method (8.85 tha ${ }^{-1}$ ) (Table 1). The 12.19\% higher straw yield was produced in SRI than conventional method. Among the interaction, $\mathrm{V}_{4}\left(10.02 \mathrm{t} \mathrm{ha}^{-1}\right)$ produced maximum straw yield in SRI that was statistically similar for $\mathrm{V}_{2}$ in SRI $\left(9.80 \mathrm{t} \mathrm{ha}^{-1}\right)$ and CM $\left(9.53 \mathrm{t} \mathrm{ha}^{-1}\right)$ followed by $\mathrm{V}_{5}\left(9.36 \mathrm{t} \mathrm{ha}^{-1}\right)$ in SRI. The minimum straw yield was produced in CM by $\mathrm{V}_{3}\left(8.38 \mathrm{t} \mathrm{ha}^{-1}\right)$ which was statistically similar for $V_{1}\left(8.64 t h^{-1}\right), V_{4}\left(8.83 t a^{-1}\right)$ and $V_{5}\left(8.85 t h a^{-1}\right)$ in CM. The higher straw yield might be due to higher amount of biomass production in extended vegetative growth period than the late transplanting in CM (Mannan et al., 2009). Das (2003) found 39 and $12 \%$ higher straw yield in SRI compared to the field practice.

Table 1. Effect of planting method on yield contributing character of inbred and hybrid rice

\begin{tabular}{|c|c|c|c|c|c|c|c|c|c|}
\hline Treatments & $\begin{array}{c}\text { Effective } \\
\text { tillers } \\
\text { (no. } \\
\text { hill }^{-1} \text { ) } \\
\end{array}$ & $\begin{array}{c}\text { Ineffective } \\
\text { tillers } \\
\text { (no. hill-1) }\end{array}$ & $\begin{array}{l}\text { Panicle } \\
\text { length } \\
\text { (cm) }\end{array}$ & $\begin{array}{c}\text { Total } \\
\text { grains } \\
\text { panicle } \\
\text { (no.) }\end{array}$ & $\begin{array}{c}\text { Filled } \\
\text { grains } \\
\text { panicle }{ }^{-1} \\
\text { (no.) }\end{array}$ & $\begin{array}{c}\text { Unfilled } \\
\text { grains } \\
\text { panicle } \\
1 \text { (no.) }\end{array}$ & $\begin{array}{l}1000- \\
\text { grains } \\
\text { weight } \\
\text { (g) }\end{array}$ & $\begin{array}{l}\text { Grain } \\
\text { yield } \\
\left(\mathrm{t} \mathrm{ha}^{-1}\right)\end{array}$ & $\begin{array}{c}\text { Straw } \\
\text { yield } \\
\left(\mathrm{t} \mathrm{ha}^{-1}\right)\end{array}$ \\
\hline $\mathrm{P}_{1}$ & $11.75 b$ & & & $172.58 \mathrm{~b}$ & $124.41 \mathrm{~b}$ & 48.17 & $25.60 \mathrm{a}$ & & \\
\hline $\mathrm{P}_{2}$ & & & & $9 \mathrm{a}$ & & & $24.13 \mathrm{~b}$ & & \\
\hline $\mathrm{LSD}_{10}$ & 267 & & 0.4 & 15.98 & 9.751 & ns & 0.889 & & \\
\hline $\mathrm{V}_{1}$ & & & & $163.60 \mathrm{c}$ & 123.30c & $40.25 b$ & $25.97 \mathrm{~b}$ & & \\
\hline $\mathrm{V}_{2}$ & & & & 29 & & & $21.42 \mathrm{c}$ & & \\
\hline & & & & & & & $6 \mathrm{~d}$ & & \\
\hline & & & & & 150. & $5 b$ & $27.25 b$ & & \\
\hline$V_{5}$ & 3 & & & 218.6 & $160.07 \mathrm{a}$ & $58.48 \mathrm{a}$ & 29.91a & 8.9 & \\
\hline LSD & & & & & & & 1.303 & & \\
\hline & & & & & & & & & \\
\hline & & & & & & & & & \\
\hline $\mathrm{P}_{1} \mathrm{~V}_{3}$ & & & & & & & & & \\
\hline & & & & & & & & & \\
\hline & & & & & & 59. & 30. & & \\
\hline & & & & & & 50.7 & $25.17 \mathrm{c}$ & & \\
\hline & & & & & & & & & \\
\hline & & & & & & & & & \\
\hline & & & & $208.3^{3}$ & 182.97ab & $25.37 \mathrm{c}$ & $25.86 c$ & & \\
\hline & & & & & & $57.67 \mathrm{~b}$ & $29.24 b$ & & \\
\hline & & & & & & 16.679 & 1.861 & 0.58 & \\
\hline
\end{tabular}

$\mathrm{P}_{1}=$ Conventional method, $\mathrm{P}_{2}=\mathrm{SRI}, \mathrm{V}_{1}=\mathrm{BR} 16, \mathrm{~V}_{2}=\mathrm{BRRI}$ dhan29, $\mathrm{V}_{3}=\mathrm{BRRI}$ dhan50, $\mathrm{V}_{4}=\mathrm{BRRI}$ hybrid dhan 2 , and $\mathrm{V}_{5}=$ Heera 4 


\section{Conclusion}

The present study showed that rice cultivation adopting SRI (single seedling hill ${ }^{-1}$ and wide spacing) produced $10.17 \%$ higher yield over the conventional method. Moreover, in SRI technique as very tiny seedlings was used that could be maintained easily in dapog seedbed and ready for transplanting in short time where it require 20 to 25 more in conventional method. Besides, AWD in SRI was a water saving method with higher benefit.

\section{Acknowledgement}

The authors are very thankful to Bangladesh Academy of Science (BAS) for providing the financial support to complete the research work.

\section{References}

Ali, M. S., M. A. Hasan, S. Sikder, M. R. Islam and M. H. R. Hafiz, 2013. Effect of seedling age and water management on the performance of boro rice (Oryza sativa L.) variety. The Agriculturists. 11(2): 28-37.

Biswas, P. K., Tohiduzzaman and T. S. Roy, 2013. Screening of rice varieties responsive to system of rice intensification (sri) in boro season. Bangladesh Agron. J. 16(1): 51-60.

Bouman, B. A., S. Peng, A. R. Castañeda and R. M. Visperas, 2005. Yield and water use of irrigated tropical aerobic rice systems. Agric. Water Mngt. 74: 87-105.

Bozorgi, H. R., A. Faraji, R. K. Danesh, A. Keshavarz, E. Azarpour and F. Tarighi, 2011. Effect of Plant Density on Yield and Yield Components of Rice. World Appl. Sci. J. 12 (11): 20532057.

Cabangon, R. J., T. P. Tuong and N. B. Abdullah, 2002. Comparing water input and water productivity of transplanted and direct-seeded rice production systems. Agric. Water Mngt. 57: 11-31.

Das, L. 2003. Varification and refinement of the System of Rice Intensification in selected areas of Bangladesh. Trial Monitoring Report. SAEF Development Group.

Ginigaddara S. G. A. and S. L. Ranamukhaarachchi, 2011. Study of age of seedlings at transplanting on growth dynamics and yield of rice under alternating flooding and suspension of irrigation of water management. Recent Res. Sci. Technol. 3(3): 76-88.

Horie, T., T. Shiraiwa, K. Homma, K. Katsura, Y. Maeda and H. Yoshida, 2005. Can yields of lowland rice resume the increases that they showed in the 1980s? Plant Production Science. 8: 251-272.

Katayama, T. 1951. Ine mugi no bungetsu kenkyu (Studies on Tillering in Rice, Wheat and Barley). Yokendo Publishing, Tokyo, Japan.

Krishna, A., N. K., Biradarpatil, K. Manjappa and B. B. Channappagoudar, 2008. Evaluation of System of Rice Intensification Cultivation, Seedling Age and Spacing on Seed Yield and Quality in Samba Masuhri (BPT-5204) Rice. Karnataka J. Agri. Sci. 21(1): 20-25.

Latif, M. A., M. R. Islama, M. Y. Alia and M. A. salequeb, 2005. Validation of the system of rice intensification (SRI) in Bangladesh. Field Crops Res. 93 (2-3): 281-292. 
Mondol et al.

Mannan, M. A., M. S. U. Bhuiya, S. M. A. Hossain and M. I. M. Akhand, 2009. Study on phenology and yielding ability of basmati fine rice genotypes as influenced by planting date in aman season. Bangladesh J. Agril. Res. 34(3): 373-384.

Mati, B. M. and M. Nyamai, 2009. Promoting the System of Rice Intensification in Kenya: Growing more with less water: an information brochure used for training on SRI in Mwea. http://www.imawesa.net/publications/training manuals/IMAWESA Training Manual5-SRI notes.

San-oh, Y., T. Sugiyama, D. Yoshhita, T. Ookawa and T. Hirasawa, 2006. The effect of planting pattern on the rate of photosynthesis and related process during ripening in rice plants. Field Crops Res. 96: 113-124.

Song, C., Z. Xi, W. Dangying, X. Chunmei and Z. Xifu, 2013. Influence of the Improved System of Rice Intensification (SRI) on Rice Yield, Yield Components and Tillering Characteristics under Different Rice Establishment Methods. Plant Prod. Sci. 16(2): 191-198.

Stoop, W. A., N. Uphoff, A. Kassam, 2002. A review of agricultural research issue raised by the System of Rice Intensification (SRI) from Madagascar: Opportunities for improving system for resource poor farmers. Agric Syst. 71: 249-274.

Suganthi, M., P. Subbian, and S. Marimuthu, 2003. Optimization of time of planting and nitrogen levels to hybrid rice (ADTRH. Madras Agric. J. 90(4-6): 339- 340.

Thakur, A. K., N. Uphoff, and E. Antony, 2009. An assessment of physiological effects of system or rice intensification (SRI) practices compared with recommended rice cultivation practices in India. Expl Agric. 46: 77-98.

Thakur, A. K., S. Rath, D. U. Patil and A. Kumar, 2011. Effects on rice plant morphology and physiology of water and associated management practices of the system of rice intensification and their implications for crop performance. Paddy Water Env. 9: 13-24.

Uphoff, N. and R. Randriamiharisoa, 2002. Reducing water use in irrigated rice production with the Madagascar System of Rice Intensification (SRI). In: Bouman et al. (Eds.). Water-wise Rice Production (pp. 71-87). Los Baños: International Rice Research Institute (IRRI).

Vermeule, M. 2009. More from less, from less to more. Scaling Up: Dissemination of a Rice Cultivation Technique. Farming Matters. Amsterfoort, the Netherlands p.3. 